\title{
The Effect of Capital Structure on the Financial Performance of Listed Companies in Bahrain Bourse
}

\author{
Ahmad Mohammad Obeid Gharaibeh \\ Dept. of Banking and Finance, College of Business and Finance, Ahlia University, Manama, Kingdom of Bahrain
}

Email address:

agharaibeh@ahlia.edu.bh

To cite this article:

Ahmad Mohammad Obeid Gharaibeh. The Effect of Capital Structure on the Financial Performance of Listed Companies in Bahrain Bourse. Journal of Finance and Accounting. Vol. 3, No. 3, 2015, pp. 50-60. doi: 10.11648/j.jfa.20150303.13

\begin{abstract}
The study investigates the effect of capital structure on the financial performance of the 17 nonfinancial companies listed in the Bahrain Bourse. The investigation was performed using 5 years data for the period from 2009 to 2013. The impact of some key macroeconomic variables (gross domestic product growth and inflation rate) on the performance of the firm was also considered in this study. Multiple regressions represented by ordinary least squares (OLS) were used to examine the effect of the independent variables (capital structure, inflation rate and GDP growth) on the financial performance measures used (ROA, ROE, EPS, and Dividend Yield)). Capital structure is encapsulated by total liabilities to total assets (TLTOTA) and total equity to total assets (EQTOTA). The results indicate that capital structure, represented by total liability to total assets, has a significantly positive impact on the performance of the firm represented by ROE, but not by ROA, EPS, and DIYILD. The results also indicate that lagged performance measures of ROA, ROE, EPS, and DYIELD have a significantly positive influence on the current year's performance measures of the firm. Moreover, the results indicate that lagged macroeconomic variables of inflation have a significantly negative relationship with certain performance measures (ROA, ROE, and EPS). Furthermore, the results indicate that gross domestic product growth (GDPG) has a significantly negative relationship with financial performance measured by EPS, but not those measured by ROA, ROE and DYIELD.
\end{abstract}

Keywords: Capital Structure, Financial Performance, ROA, ROE, EPS, Total Liability to Total Assets, Total Equity to Total Assets, Dividend Yield

\section{Introduction}

Capital structure is a term used in corporate finance to describe the mix of a company's long-term debt, some shortterm debt, common and preferred equity. The capital structure refers to how a company finances its operations and its growth by using various accessible sources of funds. When people refer to capital structure they are most likely referring to a firm's debt-to-equity ratio, which provides insight into how risky a company is 1 .

Decisions concerning the right hand side of the balance sheet of the firm (liabilities and stockholders' equity) result in a given capital structure of the firm. Suboptimal financing decisions, in the worst case scenario, could lead to corporate failure. The objective of all financing decisions is wealth maximization and the immediate way of measuring the

$1 \mathrm{http}: / /$ www.investopedia.com/terms/c/capitalstructure.asp quality of any financing decision is to examine the effect of such a decision on the firm's performance (Mwangi L. et al, 2014).

The term financial performance is a subjective measure of how well a firm can use assets from its primary mode of business to generate revenues2. It is also used as an overall measure of a company's financial health over a particular period of time.

To evaluate the financial performance of a company, one should use financial analysis to assessing the firm's profitability, leverage, solvency, and operational efficiency. The challenge is to know which ratios to choose and how to interpret the results 3 . Operating income, cash flow from operations, and total unit sales can also be used to measure

$2 \mathrm{http}: / /$ www.investopedia.com/terms/f/financialperformance.asp

3 http://www.ehow.com/how_5087042_evaluate-financial-performance.html 
the financial performance of any firm.

Financial leverage is a term used to refer to the usage of debt to finance activities and acquire additional assets in order to increase the expected return on equity. It is measured by dividing total debt by total assets or total debt by total debt and equity. Highly leveraged firms are those using substantially more debt than equity. However, this is a simplification inasmuch as the financial effects of different debt instruments vary. Where fixed cost funds predominate in financial leverage, volatility of cash flows and, thus, net income tends to increase, especially when operating income is falling. Hence, leverage can be characterized as a double edged sword, buoying corporate returns at a cost of increasing a company's risk of bankruptcy.

\subsection{Research Problem}

Capital structure decision is a crucial decision in corporate finance for almost all enterprises in the world. It consists of debt and equities with proportions that differ between firms based on many factors and variables. Both types of financing carry costs though they have their own benefits. Advantages in using debt vary; it provides a deduction on corporate tax returns (at least in jurisdictions in which corporate taxes are levied) on the interest paid; it is not dilutive from shareholders standpoint; the cost of debt is generally less than that of equity to the firm. However, using debt financing increases corporate risk level (financing risk). Additionally, the borrowing firm has to meet loan covenants and assets may be held as collateral by creditors. Finally, agency costs between creditors and shareholders may increase. The risk to shareholders is generally more than that to lenders as payment of debt takes precedence over payment of equity in law in the context of liquidation. More prosaically, bankers collect interest and amortized return of capital before shareholders can get a distribution of net income (if any). Payment of debt is required by law regardless of a company's profit margins. (Mwangi, 2014)

Financial managers as well as some other stakeholders (investors and policy-makers) of all firms around the globe conceivably will want to know the proper mix of debt and equity (capital structure) that maximizes a firm's performance. They may need to know the factors that influence the capital structure of their firms. They need to measure the influence of changing the capital structure of the firm on the profitability or the financial performance of their firm. In particular, they need to identify the relationships between financing decisions and company performance. This may vary by country, by business environment, by sector, by company, or even by time. Other factors that may influence the company's performance reflect the unique characteristics of certain economies. The findings of this study may make a contribution to the body of knowledge governing finance decisions in this milieu.

\subsection{Study Questions}

The following are the main questions that this study seeks to empirically answer:

Do capital structures influence the performance of the nonfinancial firms listed in the Bahrain Bourse?

Do macroeconomic factors influence the performance of the nonfinancial firms listed in the Bahrain Bourse and, if so, which?

Are capital structures and given macroeconomic factors positively or negatively correlated (or uncorrelated) with the performance of the firm?

What is the strength and intensity of the relationship between the capital structure and given macroeconomic factors on the performance of the firm (i.e., significant or insignificant and at what level of significance)?

\subsection{Aim and Objectives of the Study}

The general aim of this study is to explore the capital structure effects on the financial performance of the firms. It seeks to empirically measure the impact of financing decisions, if any, on the financial performance of the firm. It attempts to examine how the capital structure negatively or positively influences the firm's performance measures in the nonfinancial Bahraini firms listed in the Bahrain Bourse. Specifically, it seeks to answer the abovementioned study questions.

\subsection{Significance of the Study}

Extensive studies were conducted in this area of research in the developed countries. Still, few studies of this kind focus on Gulf cooperation Council (GCC) countries in general, and Bahrain in particular. Many studies in the finance literature have focused on and endeavored to study and identify the optimal capital structure, though it is difficult to identify. Yet, academics and scholars have largely sidestepped an examination of the financial performance effects of the capital structure in GCC countries. This study tries to investigate the effect of the capital structure on the company's financial performance. It endeavors to fill in this gap in the finance literature by investigating the effects of financial decisions on the company's performance with specific reference to a sample firms listed in Bahrain Stock Exchange (Bahrain Bourse).

\section{Literature Review and the Empirical Evidence on Impact of Capital Structure on Firm's Performance}

A firm's performance is apparently affected by numerous factors including the capital structure which could be considered as one of the prominent factors among them. Numerous studies have been conducted to explore the type of the relationships between a firm's performance and capital structure. These studies produced varied or mixed results as, for example, some found a positive, others a negative, or that no relationship exists between capital structure and the performance of the firm. 
Hutchinson (1995) claimed that debt to equity ratio (financial leverage) had a positive effect on the firm's ROE provided that earnings' power of assets exceeds the average cost of debt to the designated firm. Taub (1975) also found a significant positive relationship exists between debt ratio and profitability measures used. Besides, positive association between debt ratios and profitability of the firm were identified by Nerlove (1968), Baker (1973) and Petersen and Rajan (1994).

Examining the capital structure choice impact of firms' performance in Egypt, Ibrahim El-Sayed (2009) revealed that capital structure choice decision has a weak impact on firm's performance. He used a multiple regression analysis in estimating the relationship between financial leverage and firm's performance level. Financial performance was proxied by ROE, ROA, and Gross profit margin.

Contrarily, Nimalathasan and Valeriu Brabete (2010), in their study of manufacturing companies listed in Colombo Stock Exchange - Sri Lanka showed that the debt-equity ratio is positively and strongly associated to all profitability measures used (Gross Profit, Operating Profit and Net Profit Ratios).

Prahalathan, and Ranjani, (2011), on the other hand, assessed the Influence of capital structure choice on the firm performance and found that capital structure measured by short term debt to total assets, long term debt to total debt, total debt to total assets has no significant impact on the firm's performance measured by ROE and ROA. Remarkably, these results are at odds with other findings of the finance literature which document a significant positive or negative impact of capital structure on the firm's performance.

Mahfuzah and Yadav (2012) investigated the relationship between capital structure and firm performance. They used panel data procedure for a sample of 237 Malaysian listed companies on the Bursa Malaysia Stock exchange during 1995-2011. Four performance measures (including return on equity, return on asset, Tobin's Q and earning per share) were used as dependent variable. The five capital structure measures (including long term debt, short term debt, total debt ratios and growth) were used as independent variables. Size is a control variable. The results indicated that a firm's performance has a negative relationship with short term debt (STD), long term debt (LTD), total debt (TD). Moreover, they found positive relationships between the growth and performance for all the studied sectors. Tobin's $\mathrm{Q}$ reports demonstrate a significant positive relationship between short term debt (STD) and long term debt (LTD). It also reports that total debt (TD) has a significant negative relationship with the performance of the firm.

In his study to determine the relationship between capital structure of the firm and its performance in Pakistan, Abdul (2012) found that financial leverage has a significant negative relationship with performance as measured by gross margin (GM), return on assets (ROA), Tobin's Q and Return on Equity (ROE), though, the latter is not statistically significant.
Abbasali et. al. (2012) investigated the impact of capital structure on the financial performance of companies listed in the Tehran Stock Exchange. In their study, variables of (ROA) and (ROE) were used to measure the financial performance of companies. Results suggest that there is a significant negative relationship between debt ratio and financial performance of companies, and a significant positive relationship between asset turnover, firm size, asset tangibility ratio, and growth opportunities with financial performance measures. However, the relationship between ROA and ROE measures with the firm age were found in their study to be insignificant.

Kaumbuthu (2011) investigated the relationship between debt to equity ratio and return on equity (ROE) for the industrial sector in the Nairobi Securities Exchange (NSE). The study found a negative relationship between debt to equity ratio and ROE.

Using correlation and regression tests on financial data to explore the relationship between capital structure and financial performance of companies listed on the Karachi Stock Exchange (Pakistan), Javed and Akhtar (2012) found that a positive relationship exists between financial leverage, financial performance, and growth and size of the companies. Their findings were consistent with agency theory.

When investigating the effect of debt to equity ratios as performance measures of Kenyan firms, Maina and Kondongo (2013) found significant negative relationship between capital structure and all dependent variables used to measure the performance of the firm. They confirmed that capital structure is relevant in assessing the performance of the firm.

In a similar study, Tharmila and Arulvel (2013) examined the impact of the capital structure and financial performance of the listed companies traded in the Colombo stock exchange. Their study found that a negative relationship exists between the capital structure and financial performance.

A more recent study by Mubeen and Akhtar (2014) used the overall textile sector ROA, ROE and EPS ratios as accounting measures to evaluate the impact of capital structure on the financial performance of firms and shareholders' wealth in Pakistan. They conducted regression analysis on a sample of 155 textile firms for the years 2006 to 2011. Their results show that capital structure positively impacts firm financial performance and shareholder wealth.

To summarize, recent capital structure studies have produced diverse findings that endeavor to elucidate the impact of capital structure on the performance of the firm. Significant negative relationships between capital structure and the performance of the firm were found, for example, by Maina and Kondongo (2013), Abdul (2012), Tharmila and Arulvel (2013), Abbasali et al. (2012), and Mahfuzah and Yadav (2012). Significant positive relationships, on the other hand, were found by Javed and Akhtar (2012), Nimalathasan and Valeriu Brabete (2010), and Mubeen and Akhtar (2014). Nevertheless, mixed relationships were 
found by Stulz (1990), who noticed that debt can have positive, as well as negative, effects on the value of the firm.

\section{Methodology}

The study used actual and historical financial data obtained from published annual reports of a sample of non-financial companies listed on the Bahrain bourse (see Appendix 1). Some data were obtained from the Bahrain Bourse website. Some macroeconomic data were obtained from IMF data base. Secondary data is the data that is previously published for other purposes but found fruitful and usable for this particular research.

The utilized data encompass financial statements (balance sheets, income statements and other financial data) of the sampled companies for the period 2009-2013. The study uses data on the 17 nonfinancial companies listed in Bahrain bourse. These companies span various sectors including hotel \& tourism, services, and industry. The sample consists of:

1. THE BAHRAIN CINEMA CO. B.S.C. (CINEMA)

2. United Paper Industries B.S.C (UPI)

3. TRAFCO GROUP B.S.C. (TRAFCO)

4. SEEF PROPERTIES B.S.C. (SEEF)

5. NATIONAL HOTELS COMPANY B.S.C. (NHOTEL)

6. DELMON POULTRY CO. B.S.C. (POLTRY)

7. NASS CORPORATION B.S.C. (NASS)

8. BAHRAIN FAMILY LEISURE COMPANY B.S.C. (FAMILY)

9. BAHRAIN DUTY FREE SHOP COMPLEX B.S.C. (DUTYF)

10. BAHRAIN CAR PARK COMPANY B.S.C. (CPARK)

11. BAHRAIN TOURISM COMPANY B.S.C. (BTC)

12. BMMI B.S.C. (BMMI)

13. BAHRAIN FLOUR MILLS CO. B.S.C. (BFM)

14. Banader Hotels Company B.S.C. (BANDER)

15. BAHRAIN SHIP REPAIRING \& ENGINEERING CO. B.S.C. (BASREC)

16. BAHRAIN TELECOMMUNICATIONS COMPANY B.S.C. (BATELCO)

17. Aluminum Bahrain B.S.C. (ALBH)

\subsection{The Study Hypotheses}

In order to investigate the effect of capital structure on the financial performance of the firm, the following alternative hypotheses were designed and used for testing:

H1: there is a statistically significant relationship between capital structure and ROA of the firm.

$\mathrm{H} 2$ : there is a statistically significant relationship between capital structure and ROE of the firm.

H3: there is a statistically significant relationship between capital structure and EPS of the firm.

H4: there is a statistically significant relationship between capital structure and DYIELD of the firm.

H5: there is a statistically significant relationship between GDP growth and performance of the firm.

H6: there is a statistically significant relationship between inflation rate (INFL) and performance of the firm.

These hypotheses will be tested by examining the effects of each of the independent variables on the dependent variables encompassing the financial performance.

\subsection{The Study Model}

The model used in this study incorporates dependent as well as independent variables. The independent variables encompass capital structure and include debt to equity ratio (total liability to total equity), total equity to total assets ratio. Inflation rate (INFL) and Gross domestic product growth (GDPG) were also included in the independent variables. The traditional theory of capital structure was employed to determine the significance of leverage and macroeconomic variables on firm's performance (Ogebe et al 2013). The dependent variables encompass the accounting measures of financial performance of the firm include: Earning per share (EPS), return on equity (ROE), return on assets (ROA), and dividend yield (DYIELD). The original framework of this study is adapted from the old capital structure theory. Nonetheless, it is augmented with some macroeconomic variables (gross domestic product growth and inflation rate) to determine their impact of on the firm's performance.

In order to test the hypotheses of this research, the following model is used.

PERF $_{\mathrm{i}, \mathrm{t}}=\mathrm{f}($ EQTOTA, GDPG, INFL, TLTOTA $)$

$$
\begin{gathered}
\text { ROE }_{\mathrm{i}, \mathrm{t}}=\alpha+\beta_{1} \mathrm{ROE}_{\mathrm{i}, \mathrm{t}-1}+\beta_{2} \text { EQTOTA }_{\mathrm{i}, \mathrm{t}}+\beta_{3} \mathrm{GDPG}_{\mathrm{i}, \mathrm{t}}+\beta_{4} \mathrm{INFL}_{\mathrm{i}, \mathrm{t}}+\beta_{5} \mathrm{TLTOTA}_{\mathrm{i}, \mathrm{t}}+\varepsilon_{\mathrm{t}} \\
\text { ROA }_{\mathrm{i}, \mathrm{t}}=\alpha+\beta_{1} \mathrm{ROA}_{\mathrm{i}, \mathrm{t}-1}+\beta_{2} \mathrm{EQTOTA}_{\mathrm{i}, \mathrm{t}}+\beta_{3} \mathrm{GDPG}_{\mathrm{i}, \mathrm{t}}+\beta_{4} \mathrm{INFL}_{\mathrm{i}, \mathrm{t}}+\beta_{5} \mathrm{TLTOTA}_{\mathrm{i}, \mathrm{t}}+\varepsilon_{\mathrm{t}} \\
\text { DYIELD }_{\mathrm{i}, \mathrm{t}}=\alpha+\beta_{1} \text { DYIELD }_{\mathrm{i}, \mathrm{t}-1}+\beta_{2} \text { EQTOTA }_{\mathrm{i}, \mathrm{t}}+\beta_{3} \mathrm{GDPG}_{\mathrm{i}, \mathrm{t}}+\beta_{4} \mathrm{INFL}_{\mathrm{i}, \mathrm{t}}+\beta_{5} \mathrm{TLTOTA}_{\mathrm{i}, \mathrm{t}}+\varepsilon_{\mathrm{t}} \\
\text { EPS }_{\mathrm{i}, \mathrm{t}}=\alpha+\beta_{1} \mathrm{EPS}_{\mathrm{i}, \mathrm{t}-\mathrm{t}}+\beta_{2} \text { EQTOTA }_{\mathrm{i}, \mathrm{t}}+\beta_{3} \mathrm{GDPG}_{\mathrm{i}, \mathrm{t}}+\beta_{4} \mathrm{INFL}_{\mathrm{i}, \mathrm{t}}+\beta_{5} \mathrm{TLTOTA}_{\mathrm{i}, \mathrm{t}}+\varepsilon_{\mathrm{t}}
\end{gathered}
$$

Where:

$\mathrm{PERF}_{i, t}=$ financial performance of firm $i$ in year $t$

$\mathrm{ROE}_{i, t}=$ return on equity of firm $i$ in year $t$

$\mathrm{ROA}_{\mathrm{i}, \mathrm{t}}=$ return on assets of firm $i$ in year $t$

DYIELD $_{\mathrm{i}, \mathrm{t}}=$ dividend yield of firm $i$ in year $t$

EPS $_{\mathrm{i}, \mathrm{t}}=$ earnings per share of firm $i$ in year $t$

EQTOTA $_{i, t}=$ equity to total assets of firm $i$ in year $t$
TLTOTA $_{i, t}=$ total liability to total assets of firm $\mathrm{i}$ in year $\mathrm{t}$ $\mathrm{INFL}_{\mathrm{i}, \mathrm{t}}=$ inflation rate for country $i$ in year $t$, where the country here is Bahrain.

$\mathrm{GDPG}_{\mathrm{i}, \mathrm{t}}=$ gross domestic product growth for country $i$ in year $t$, where the country here is Bahrain.

$\alpha=$ Constant term

$\beta_{\mathrm{s}}$ are coefficients of the explanatory variables 
$\varepsilon_{\mathrm{t}}=$ composite error term

\section{Research Findings}

The following sections represent the findings of the study. They include the descriptive statistics, correlation analysis in addition to multiple regression analysis.

\subsection{Descriptive Statistics}

Table 1 shows the Mean, Maximum, Minimum, Standard deviation, and Skewness statistics.

Table 1: Descriptive Statistics

\begin{tabular}{|c|c|c|c|c|c|c|c|c|c|}
\hline & DYIELD & EPS & EQTOTA & GDPG & INFL & ROA & ROE & TLTOTA & TLTOTE \\
\hline Mean & 0.055949 & 0.042904 & 64.67678 & 0.036052 & 0.020498 & 0.074319 & 0.091145 & 0.191475 & 0.292048 \\
\hline Median & 0.061700 & 0.033000 & 0.848000 & 0.035887 & 0.027546 & 0.075900 & 0.080800 & 0.153187 & 0.180000 \\
\hline Maximum & 0.111100 & 0.163000 & 5302.000 & 0.053375 & 0.031892 & 0.196000 & 0.290000 & 0.517600 & 1.110000 \\
\hline Minimum & 0.000000 & -0.070000 & 0.467500 & 0.021002 & -0.003644 & -0.136500 & -0.150800 & 0.035938 & 0.010000 \\
\hline Std. Dev. & 0.027377 & 0.038160 & 581.8815 & 0.011873 & 0.012976 & 0.051886 & 0.067206 & 0.146789 & 0.299156 \\
\hline Skewness & -0.456971 & 0.790079 & 8.944953 & 0.138401 & -1.133785 & -0.555055 & 0.266004 & 0.829733 & 1.220563 \\
\hline
\end{tabular}

As it is clear in Table 1, the mean value of Dividend Yield for the 83 observations of the study is $5.5949 \%$ with a standard deviation of $2.7377 \%$. The positive dividend yield figures indicate that most of these companies have distributed dividends; however, a few have not, evidenced in instances in which the minimum value is zero. The mean value for ROA is $7.4319 \%$ which indicates that most companies were profitable (though some of them were suffering some losses as indicated by the minimum value of $-13.65 \%$ ). Similarly, the mean value for ROE is found to be, as shown in the Table, $9.1145 \%$ which indicates, also, that most of the surveyed companies were profitable though some of them were suffering some losses as indicated by the minimum value of $15.08 \%$. Earnings per share (EPS), as the Table reveals, have a mean of $4.2904 \%$ reflecting the profitability of the overall surveyed firms. The negative minimum value of EPS (-7\%) indicates that some firms were suffering some losses. The low standard deviations figures mean that most of the firms are in the same range of profitability and performance. Negative and positive values of skewness mean that the results, to a certain extent, are not normally distributed.

\subsection{Correlation Analysis}

This study used the correlation and multiple regression analyses to test the hypotheses. The results were analyzed based on statistical significance and insignificant coefficients.

Table 2: Correlation between capital structure and the financial performance variables

\begin{tabular}{|c|c|c|c|c|c|c|c|c|c|}
\hline & DYIELD & EPS & EQTOTA & GDPG & INFL & ROA & ROE & TLTOTA & TLTOTE \\
\hline DYIELD & 1.000000 & & & & & & & & \\
\hline EPS & 0.199620 & 1.000000 & & & & & & & \\
\hline EQTOTA & 0.009882 & -0.072510 & 1.000000 & & & & & & \\
\hline GDPG & -0.094461 & -0.037474 & 0.068230 & 1.000000 & & & & & \\
\hline INFL & -0.116303 & 0.017796 & -0.007520 & 0.650021 & 1.000000 & & & & \\
\hline ROA & 0.471682 & 0.686311 & -0.078832 & 0.028689 & 0.033525 & 1.000000 & & & \\
\hline ROE & 0.456894 & 0.600234 & -0.033872 & 0.045995 & 0.022644 & 0.843387 & 1.000000 & & \\
\hline TLTOTE & 0.258409 & -0.012364 & 0.195824 & 0.046568 & -0.019300 & -0.054016 & 0.276901 & 0.984420 & 1.000000 \\
\hline
\end{tabular}

This study utilizes the correlation coefficient as a method to explore the type and intensity of the relationship between the dependent and independent variables (i.e., the capital structure of the firm and its performance). Using the E-views analysis tool, the following results were obtained. Table 2 displays the relationships between the study variables. Particularly the individual relationships between dependent variables represented by total liabilities to total equities (TLTOTE), total equities to total assets (EQTOTA), Total liabilities to total assets (TLTOTA), gross domestic product growth (GDPG), inflation rate (INFL) and the dependent variables represented by accounting measures of firm performance including dividend yield (DYIELD), earnings per share (EPS), return on equity (ROE) and return on assets (ROA). To avoid multi co-linearity, the total liability to total equity (TLTOTE) variable was excluded from the analysis.

Table 2 above illustrates the correlation between capital structure variables and the financial performance variables of firms. It shows that a positive relationship exists between the dependent variables (DYIELD, EPS, ROA, and ROE) of the study. This probably means that even if one of these had been used as a surrogate for financial performance, the same outcomes would have obtained from the study analysis.

The table also shows that positive relationships exist among capital structure variables, as reflected by the positive correlation between equity to total assets (EQTOTA), total liabilities to total assets (TLTOTA), and total liabilities to total equity (TLTOTE).

However, the Table shows negative relationships exist between some of the dependent variables and independent 
variables. Dividend yield (DYIELD), for example, has a negative correlation with gross domestic product growth (GDPG) and inflation rate (INFL). A negative relationship also exists between EPS on the one hand and equity to total assets, gross domestic product growth and total liabilities to total equity on the other. This explains the phenomenon that, "underleverage" (too much equity) depresses earning per share as earnings are distributed over a larger number of shares. ROA has a negative correlation with total liabilities to total assets as well as with total liabilities to total equity.

\subsection{Regression Analysis and Discussions}

In order to examine the impact of the capital structure (independent variable) on the financial performance (dependent variable) of the study sample, regression analysis is used. For decision making criteria, adjusted r-squared, pvalue, and Durbin-Watson statistics were used.

P-value (prob.) is the probability value used in this study as criteria to whether accept or reject the null or alternative hypothesis. A P-value of less than or equal to 0.01 means that the null hypothesis is rejected and the alternative hypothesis is accepted at $1 \%$ level of significance. A p-value of less than or equal to 0.05 means that the null hypothesis is rejected and the alternative hypothesis is accepted at 5\% level of significance. A p-value of less than or equal to 0.10 means that the null hypothesis is rejected and the alternative hypothesis is accepted at $10 \%$ level of significance.

The Adjusted $R^{2}$ is a measure used in multiple regression analysis of a goodness-of-fit that penalizes additional explanatory variables through using a degrees of freedom adjustment when estimating the variance error. It adjusts for the number of explanatory terms in a model relative to the number of data points.

Durbin-Watson Statistic (DW) is a statistical method used to test for first order serial correlation in the errors of a regression model (Wooldridge, 2004).DW helps in specifying the right combination of explanatory variables (Gujarati, 2004). Durbin and Watson (1950 and 1951) applied this statistic to the residuals from ordinary least squares regressions and developed bounds tests for the null hypothesis that the errors are serially uncorrelated against the alternative that follow a first order autoregressive process.

The following Tables represent the relationships between the dependent and independent variables:

Table 3: Regression analysis between the capital structure (TLTOTA and EQTOTA), GDPG, INFL rate, and ROA

\begin{tabular}{|c|c|c|c|c|}
\hline Variable & Coefficient & Std. Error & t-Statistic & Prob. \\
\hline $\mathrm{C}$ & 0.070594 & 0.023224 & 3.039629 & 0.0033 \\
\hline ROA(-1) & 0.362621 & 0.103137 & 3.515898 & $0.0007 * * *$ \\
\hline EQTOTA & $-8.63 \mathrm{E}-06$ & $9.56 \mathrm{E}-06$ & -0.903206 & 0.3693 \\
\hline GDPG_ & -0.150508 & 0.473338 & -0.317971 & 0.7514 \\
\hline $\operatorname{INFL}(-1)$ & -0.886220 & 0.430477 & -2.058694 & $0.0430 * *$ \\
\hline TLTOTA & 0.002904 & 0.037572 & 0.077299 & 0.9386 \\
\hline R-squared & 0.183597 & \multicolumn{2}{|c|}{ Mean dependent var } & 0.073816 \\
\hline Adjusted R-squared & 0.129170 & \multicolumn{2}{|c|}{ S.D. dependent var } & 0.051657 \\
\hline S.E. of regression & 0.048206 & \multicolumn{2}{|c|}{ Akaike info criterion } & -3.155500 \\
\hline Sum squared resid & 0.174283 & \multicolumn{2}{|c|}{ Schwarz criterion } & -2.978134 \\
\hline Log likelihood & 133.7978 & \multicolumn{2}{|c|}{ Hannan-Quinn criter. } & -3.084338 \\
\hline F-statistic & 3.373268 & \multicolumn{2}{|c|}{ Durbin-Watson stat } & 2.148410 \\
\hline Prob(F-statistic) & 0.008391 & & & \\
\hline
\end{tabular}

$* * *, * *$, and $*$, signify $1 \%, 5 \%$ and $10 \%$ respectively.

Table 3, shows the coefficient of equity to total assets (EQTOTA) of $-8.63 \mathrm{E}-06$ is statistically insignificant at $10 \%$ level with p-value of 0.3693 . It also shows the coefficient of total liabilities to total assets (TLTOTA) of 0.002904 is statistically insignificant at $10 \%$ level with p-value of 0.9386 . This indicates that there is no significant relationship between capital structure and return on assets (ROA). Therefore, the first hypothesis that there is a statistically significant relationship between capital structure and ROA of the firm is rejected. Additionally, GDPG is revealed to have no significant relationship with ROA.

However, the table shows the lagged inflation rate (INFL (-1)) coefficient of -0.886220 is negative and statistically significant at $5 \%$ level with a p-value of 0.0430 . Therefore, the sixth hypothesis that there is a statistically significant relationship between inflation rate (INFL) and performance of the firm is accepted. This result is not consistent with
Ogebe et al (2013) who found positive and insignificant relationship between macroeconomic variables and performance of the firm.

Table 3 also shows that the lagged return on assets (ROA $(-1)$ ) coefficient of 0.362621 is positive and statistically significant at $1 \%$ level of significance $(p=0.0007)$. This significant positive relationship implies that previous years ROA explains the current year's data.

Durbin-Watson Statistic is used to test the presence of autocorrelation in the residuals (prediction errors) from a regression analysis. The Durbin-Watson statistic of 2.148410, as revealed by the Table shows an absence of autocorrelation. It implies neither underestimation nor overestimation of the level of statistical significance.

The use of an adjusted $\mathrm{R}^{2}$ is an attempt to take account of the phenomenon of the $\mathrm{R}^{2}$ automatically and spuriously increasing when extra explanatory variables are added to the 
model. The adjusted R-squared of 0.129170 means that variations in the independent variables can explain the variations in the dependent variables by $12.9170 \%$.
Accordingly, elicited conclusions can be considered as credibly supported by the data.

Table 4: Regression analysis between the capital structure (TLTOTA and EQTOTA), GDPG, INFL rate, and ROE

\begin{tabular}{|c|c|c|c|c|}
\hline Variable & Coefficient & Std. Error & t-Statistic & Prob. \\
\hline $\mathrm{C}$ & 0.057843 & 0.026757 & 2.161791 & 0.0338 \\
\hline $\operatorname{ROE}(-1)$ & 0.468770 & 0.097474 & 4.809191 & $0.0000 * * *$ \\
\hline EQTOTA & $-1.25 \mathrm{E}-05$ & $1.13 \mathrm{E}-05$ & -1.114314 & 0.2687 \\
\hline GDPG_ & -0.168486 & 0.557698 & -0.302110 & 0.7634 \\
\hline $\operatorname{INFL}(-\overline{1})$ & -1.092070 & 0.506868 & -2.154544 & $0.0344 * *$ \\
\hline TLTOTA & 0.106577 & 0.045136 & 2.361243 & $0.0208^{* *}$ \\
\hline R-squared & 0.337353 & Mean dependent var & & 0.090570 \\
\hline S.E. of regression & 0.056769 & Akaike info criterion & & -2.828452 \\
\hline Sum squared resid & 0.241707 & Schwarz criterion & & -2.651086 \\
\hline Log likelihood & 120.5523 & Hannan-Quinn criter. & & -2.757290 \\
\hline F-statistic & 7.636482 & Durbin-Watson stat & & 2.195425 \\
\hline Prob(F-statistic) & 0.000008 & & & \\
\hline
\end{tabular}

$* * *, * *$, and $*$, signify $1 \%, 5 \%$ and $10 \%$ respectively.

Table 4 represents the regression analysis between the capital structure (TLTOTA) on the one hand and EQTOTA), GDPG, INFL rate, and ROE on the other. It shows a significant positive relationship exists between return on equity (ROE) and total liabilities to total assets with level of significance at $5 \%$ and a p-value of 0.0208 . This suggests that increases in total debt, at least on the margin, will improve the performance of the firm. Therefore, the second hypothesis that there is a statistically significant relationship between capital structure and ROE of the firm is accepted. This result is consistent with the research results of Mahfuzah and Yadav (2012), Abdul (2012), Abbasali et al. (2012) and Kaumbuthu (2011). However, it is not consistent with the results of Hutchinson (1995), Taub (1975), Nerlove (1968), Baker (1973) and Petersen, Rajan (1994), and Nimalathasan and Valeriu Brabete (2010) and Maina and Kondongo (2013). Lagged inflation (INFL (-1)) also has been found to have a negatively significant relationship with ROE with level of significance at $5 \%$ and prob. value of 0.0344 . Therefore, the sixth hypothesis that there is a statistically significant relationship between inflation rate (INFL) and performance of the firm is accepted. In addition, the lagged return on equity $\operatorname{ROE}(-1)$ is found to have a statistically significant positive relationship at $1 \%$ level of significance $(p$ $=0.0000)$. This significant positive relationship implies that previous years ROE explains the current year's data. This result is consistent with the results of Ogebe et al (2013). GDPG, on the other hand, was found to have an insignificant relationship with ROE.

The Durbin-Watson statistic of 2.195425 implies, for all practical purposes, that there is neither underestimation nor overestimation of the level of statistical significance. It credibly demonstrates an absence of auto correlation.

The adjusted $\mathrm{R}^{2}$ reflects the amount of variance in the outcome mimicked in the population. The adjusted R-squared of 0.293176 means that variations in the independent variables can explain the variations in the dependent variables by $29.3176 \%$. This result convincingly supports the explanatory power of the model.

Table 5: Regression analysis between the capital structure (TLTOTA and EQTOTA), GDPG, INFL rate, and EPS

\begin{tabular}{|c|c|c|c|c|}
\hline Variable & Coefficient & Std. Error & t-Statistic & Prob. \\
\hline $\mathrm{C}$ & 0.048490 & 0.013119 & 3.696257 & 0.0004 \\
\hline EPS(-1) & 0.653806 & 0.084245 & 7.760809 & $0.0000 * * *$ \\
\hline EQTOTA & $-3.77 \mathrm{E}-06$ & $5.61 \mathrm{E}-06$ & -0.670609 & 0.5045 \\
\hline GDPG_ & -0.543394 & 0.278710 & -1.949679 & $0.0550 *$ \\
\hline $\operatorname{INFL}(-1)$ & -0.625951 & 0.252295 & -2.481030 & $0.0153 * *$ \\
\hline TLTOTA & -0.006896 & 0.022235 & -0.310139 & 0.7573 \\
\hline R-squared & 0.472918 & Mean dependent var & & 0.042309 \\
\hline S.E. of regression & 0.028257 & Akaike info criterion & & -4.223796 \\
\hline Sum squared resid & 0.059882 & Schwarz criterion & & -4.046429 \\
\hline Log likelihood & 177.0637 & Hannan-Quinn criter. & & -4.152634 \\
\hline F-statistic & 13.45858 & Durbin-Watson stat & & 2.020669 \\
\hline Prob(F-statistic) & 0.000000 & & & \\
\hline
\end{tabular}

$* * *, * *$, and $*$, signify $1 \%, 5 \%$ and $10 \%$ respectively.

Table 5 represents the regression analysis between capital structure (TLTOTA) on the one hand and EQTOTA), GDPG, INFL rate, and EPS on the other. It shows a significant negative relationship exists between EPS and gross domestic product growth rate (GDPG) with a level of significance at $10 \%$ and a $\mathrm{p}$-value of 0.0550 . Therefore, the fifth hypothesis 
that there is a statistically significant relationship between GDP growth and performance of the firm is accepted. Lagged EPS, on the other hand, has been found to have a positive significant relationship at $1 \%$ level with current year's EPS. This significant positive relationship implies that previous years' EPS explains the current year's data. The Table also shows that lagged inflation rate (INFL_ (-1)) with a coefficient of -0.625951 is negatively statistically significant at $5 \%$ level with a p-value of 0.0153 . This means that the sixth hypothesis that there is a statistically significant relationship between inflation rate (INFL) and performance of the firm is accepted. TLTOTA, on the other hand, was found to have no significant relationship with EPS. This implies that the third hypothesis that there is a statistically significant relationship between capital structure and EPS of the firm is failed to reject. This result is consistent with the research results of Mahfuzah and Yadav (2012), Tharmila and Arulvel (2013), and Maina and Kondongo (2013), However, it is inconsistent with the results of Mubeen and Akhtar (2014).

The Durbin-Watson statistic of 2.020669 implies, for all practical purposes, that there is neither underestimation nor overestimation of the level of statistical significance.

The adjusted R-squared of 0.437779 means that variations in the independent variables can explain the variations in the dependent variables by $43.7779 \%$. This result strongly supports the explanatory power of the model.

Table 6: Regression analysis between the capital structure (TLTOTA and EQTOTA), GDPG, INFL rate, and DYIELD

\begin{tabular}{lllc}
\hline Variable & Coefficient & Std. Error & t-Statistic \\
\hline C & 0.027583 & 0.012186 & 2.263459 \\
DYIELD(-1) & 0.526623 & 0.099782 & 5.277733 \\
EQTOTA & $-1.39 \mathrm{E}-06$ & $4.64 \mathrm{E}-06$ & -0.299266 \\
GDPG_ & -0.135658 & 0.227671 & -0.595851 \\
INFL(-1) & 0.027886 & 0.211071 & 0.132116 \\
TLTOTA & 0.017829 & 0.018804 & 0.7656 \\
R-squared & 0.316310 & Mean dependent var & 0.9530 \\
Adjusted R-squared & 0.271331 & S.D. dependent var & 0.8952 \\
S.E. of regression & 0.023454 & Akaike info criterion & \\
Sum squared resid & 0.041808 & Schwarz criterion & \\
Log likelihood & 194.4840 & Hannan-Quinn criter. & \\
F-statistic & 7.032312 & Durbin-Watson stat & \\
Prob(F-statistic) & 0.000019 & & -4.056162 \\
\hline
\end{tabular}

$* * *, * *$, and $*$, signify $1 \%, 5 \%$ and $10 \%$ respectively.

Table 6 represents the regression analysis between the capital structure (TLTOTA) on the one hand and EQTOTA), GDPG, INFL rate, and DYIELD on the other. It shows an insignificant negative relationship exists between DYIELD and gross domestic product growth rate (GDPG) with a coefficient of -0.135658 and $p$-value of 0.5530 . Previous year's DYIELD was found to have a positive significant relationship with a coefficient value of 0.526623 and p-value of 0.0000 with current year's DYIELD. This significant positive relationship implies that previous years' DYIELD explains the current year's data. GDPG, INFL (-1), and TLTOTA, on the other hand, were found to have insignificant relationships with DYIELD.

The Durbin-Watson statistic of 2.461984 implies that there is no substantive underestimation or overestimation of the level of statistical significance. To a certain extent, it shows no positive autocorrelation with, at worst, a marginal level of negative autocorrelation.

The adjusted R-squared of 0.271331 means that variations in the independent variables can explain the variations in the dependent variables by $27.1331 \%$. This result is very reasonable.

\section{Conclusions}

This study has empirically investigated the impact of capital structure on the financial performance of 17 nonfinancial Bahraini firms listed in the Bahrain Bourse. The study also verified the effects of macroeconomic variables; inflation rate (INFL) and gross domestic product growth (GDPG)) on the performance of the firm. The study used earning per share (EPS), return on equity (ROE), return on assets (ROA), and dividend yield (DYIELD) as surrogates to measure the financial performance of the firm. Total liability to total assets (TLTOTA), total liability to total equity (TLTOTE), and total equity to total assets (EQTOTA) ratios were used as measures of capital structure.

The empirical results indicate that capital structure, represented by total liability to total assets (TLTOTA), positively influences the performance of the firm as represented by ROE. This finding comports with the results of Hutchinson (1995), Taub (1975), Nerlove (1968), Baker (1973) and Petersen, Rajan (1994), Nimalathasan and Valeriu Brabete (2010) and Maina and Kondongo (2013). However, it is not consistent with the results of Mahfuzah and Yadav (2012), Abdul (2012), Abbasali et al. (2012) and Kaumbuthu (2011). On the other hand, the results indicate that TLTOTA has no statistically significant impact on the performance of the firm measured by ROA, EPS, and DIYILD. This result is consistent with Prahalathan, and Ranjani, (2011). Equity to total assets, as the results indicate, proved to have no significant impact on any of the performance measured used (i.e., ROA, ROE, EPS, and DYIELD). This finding comports with the results of Ibrahim El-Sayed (2009). 
The results also indicate that lagged performance measures (ROA (-1), ROE (-1), EPS (-1), and DYIELD (-1)) correlate positively to a significant extent, with equivalent current year's performance measures of the firm. In addition, the results show that lagged macroeconomic variables (INFL (-1)) have a significant negative relationship with performance measures (ROA, ROE, and EPS). This result deviates from the findings of Ogebe et al (2013). Moreover, gross domestic product growth, as the results show, has a statistically significant relationship with earnings per share (EPS).

\section{Appendix 1}

Table 7: Actual historical financial data obtained of the sampled companies for the period 2009-2013

\begin{tabular}{|c|c|c|c|c|c|c|c|c|c|c|}
\hline & & EPS & ROE & ROA & TL/TE & EQ/TA & DYIELD & GDPG & INFL & TL/TA \\
\hline \multirow{5}{*}{ CINEMA } & 2013 & 0.115 & 0.1618 & 0.1514 & 0.11 & 0.908 & 0.0385 & 0.053375385 & 0.031892481 & 0.099237926 \\
\hline & 2012 & 0.081 & 0.1312 & 0.121 & 0.08 & 0.9217 & 0.05 & 0.035887046 & 0.027545536 & 0.078263003 \\
\hline & 2011 & 0.05 & 0.0846 & 0.0798 & 0.07 & 0.9352 & 0.0641 & 0.021001841 & -0.003644478 & 0.064746331 \\
\hline & 2010 & 0.096 & 0.1281 & 0.1188 & 0.08 & 0.9275 & 0.0556 & 0.043344071 & 0.019618847 & 0.072542482 \\
\hline & 2009 & 0.084 & 0.1175 & 0.1094 & 0.07 & 0.9312 & 0.0667 & 0.025397725 & 0.027955128 & 0.068840261 \\
\hline \multirow{5}{*}{ UPI } & 2013 & 0.055 & 0.1782 & 0.0864 & 0.98 & 0.5045 & 0.0665 & 0.053375385 & 0.031892481 & 0.495570564 \\
\hline & 2012 & 0.026 & 0.0923 & 0.041 & 0.86 & 0.5386 & 0.0476 & 0.035887046 & 0.027545536 & 0.461402109 \\
\hline & 2011 & 0.024 & 0.0875 & 0.0401 & 0.77 & 0.5646 & 0.0357 & 0.021001841 & -0.003644478 & 0.43539032 \\
\hline & 2010 & 0.046 & 0.159 & 0.0803 & 0.61 & 0.6204 & 0.0357 & 0.043344071 & 0.019618847 & 0.379541109 \\
\hline & 2009 & N/A & N/A & N/A & N/A & N/A & 0.0476 & 0.025397725 & 0.027955128 & N/A \\
\hline \multirow{5}{*}{ TRAFCO } & 2013 & 0.019 & 0.067 & 0.038 & 0.71 & 0.5674 & 0.0537 & 0.053375385 & 0.031892481 & 0.400333864 \\
\hline & 2012 & 0.018 & 0.072 & 0.0385 & 0.81 & 0.5364 & 0.0522 & 0.035887046 & 0.027545536 & 0.43447229 \\
\hline & 2011 & 0.021 & 0.0779 & 0.0406 & 0.86 & 0.5204 & 0.0692 & 0.021001841 & -0.003644478 & 0.447295354 \\
\hline & 2010 & 0.018 & 0.0707 & 0.0375 & 0.82 & 5302 & 0.0584 & 0.043344071 & 0.019618847 & 0.432894805 \\
\hline & 2009 & 0.02 & 0.077 & 0.04 & 0.89 & 0.5142 & 0.0571 & 0.025397725 & 0.027955128 & 0.457362343 \\
\hline \multirow{4}{*}{ SEEF } & 2012 & 0.018 & 0.0701 & 0.0668 & 0.05 & 0.9521 & 0.0703 & 0.035887046 & 0.027545536 & 0.047864227 \\
\hline & 2011 & 0.019 & 0.076 & 0.0721 & 0.05 & 0.9488 & 0.0843 & 0.021001841 & -0.003644478 & 0.051156707 \\
\hline & 2010 & 0.02 & 0.0868 & 0.0821 & 0.06 & 0.9468 & 0.0658 & 0.043344071 & 0.019618847 & 0.05322394 \\
\hline & 2009 & 0.015 & 0.0698 & 0.0648 & 0.08 & 0.9275 & 0.0338 & 0.025397725 & 0.027955128 & 0.072516456 \\
\hline \multirow{5}{*}{ NHOTEL } & 2013 & 0.026 & 0.0318 & 0.0272 & 0.17 & 0.8561 & 0.027 & 0.053375385 & 0.031892481 & 0.143866609 \\
\hline & 2012 & 0.021 & 0.0293 & 0.0234 & 0.26 & 0.7968 & 0.0244 & 0.035887046 & 0.027545536 & 0.203205489 \\
\hline & 2011 & 0.025 & 0.0395 & 0.0278 & 0.25 & 0.7999 & 0.0225 & 0.021001841 & -0.003644478 & 0.200075013 \\
\hline & 2010 & 0.071 & 0.1041 & 0.0883 & 0.18 & 0.848 & 0.0449 & 0.043344071 & 0.019618847 & 0.151957109 \\
\hline & 2009 & 0.061 & 0.0955 & 0.0884 & 0.08 & 0.9253 & 0.0449 & 0.025397725 & 0.027955128 & 0.074706011 \\
\hline \multirow{5}{*}{ POLTRY } & 2013 & 0.026 & 0.0538 & 0.0516 & 0.04 & 0.9585 & 0.0641 & 0.053375385 & 0.031892481 & 0.041510893 \\
\hline & 2012 & 0.038 & 0.0806 & 0.0759 & 0.06 & 0.9424 & 0.0833 & 0.035887046 & 0.027545536 & 0.057628659 \\
\hline & 2011 & 0.038 & 0.0839 & 0.0792 & 0.06 & 0.9445 & 0.093 & 0.021001841 & -0.003644478 & 0.055487887 \\
\hline & 2010 & 0.032 & 0.0715 & 0.0681 & 0.05 & 0.9532 & 0.093 & 0.043344071 & 0.019618847 & 0.046850313 \\
\hline & 2009 & 0.044 & 0.0985 & 0.0939 & 0.05 & 0.9534 & 0.0885 & 0.025397725 & 0.027955128 & 0.046643668 \\
\hline \multirow{3}{*}{ NASS } & 2013 & 0.019 & 0.0742 & 0.0417 & 0.75 & 0.5615 & 0.0932 & 0.053375385 & 0.031892481 & 0.419584941 \\
\hline & 2010 & 0.034 & 0.139 & 0.0715 & 0.89 & 0.5145 & 0.0781 & 0.043344071 & 0.019618847 & 0.459740361 \\
\hline & 2009 & 0.064 & 0.2754 & 0.1368 & 0.96 & 0.4966 & 0.0775 & 0.025397725 & 0.027955128 & 0.476637281 \\
\hline \multirow{5}{*}{ FAMILY } & 2013 & 0.032 & 0.29 & 0.196 & 0.07 & 0.938 & 0 & 0.053375385 & 0.031892481 & 0.062027231 \\
\hline & 2012 & 0.011 & 0.0857 & 0.0778 & 0.01 & 0.9071 & 0.0714 & 0.035887046 & 0.027545536 & 0.092775518 \\
\hline & 2011 & -0.001 & -0.0123 & -0.011 & 0.12 & 0.8927 & 0 & 0.021001841 & -0.003644478 & 0.107358766 \\
\hline & 2010 & 0.014 & 0.1114 & 0.1019 & 0.09 & 0.915 & 0.0815 & 0.043344071 & 0.019618847 & 0.085038744 \\
\hline & 2009 & -0.017 & -0.1508 & -0.1365 & 0.01 & 0.9075 & 0 & 0.025397725 & 0.027955128 & 0.094289509 \\
\hline \multirow{5}{*}{ DUTYF } & 2013 & 0.06 & 0.0719 & 0.13 & 0.18 & 0.8421 & 0.0719 & 0.053375385 & 0.031892481 & 0.15534946 \\
\hline & 2012 & 0.065 & 0.0694 & 0.1422 & 0.19 & 0.8392 & 0.0694 & 0.035887046 & 0.027545536 & 0.158298825 \\
\hline & 2011 & 0.055 & 0.0752 & 0.1282 & 0.18 & 0.8431 & 0.0752 & 0.021001841 & -0.003644478 & 0.153187123 \\
\hline & 2010 & 0.071 & 0.0565 & 0.1493 & 0.21 & 0.8263 & 0.0565 & 0.043344071 & 0.019618847 & 0.170122313 \\
\hline & 2009 & 0.09 & 0.0621 & 0.157 & 0.26 & 0.791 & 0.0621 & 0.025397725 & 0.027955128 & 0.207498401 \\
\hline \multirow{5}{*}{ CPARK } & 2013 & 0.012 & 0.0676 & 0.0651 & 0.04 & 0.964 & 0.0532 & 0.053375385 & 0.031892481 & 0.035938347 \\
\hline & 2012 & 0.011 & 0.0639 & 0.0609 & 0.05 & 0.953 & 0.0667 & 0.035887046 & 0.027545536 & 0.046958543 \\
\hline & 2011 & 0.011 & 0.0594 & 0.0568 & 0.05 & 0.9565 & 0.0645 & 0.021001841 & -0.003644478 & 0.043560013 \\
\hline & 2010 & 0.018 & 0.1 & 0.0962 & 0.04 & 0.9619 & 0.0667 & 0.043344071 & 0.019618847 & 0.038062554 \\
\hline & 2009 & 0.015 & 0.0881 & 0.0847 & 0.04 & 0.9618 & 0.075 & 0.025397725 & 0.027955128 & 0.038182697 \\
\hline \multirow{4}{*}{ BTC } & 2013 & 0.017 & 0.0345 & 0.0318 & 0.08 & 0.9229 & 0.06 & 0.053375385 & 0.031892481 & 0.077082785 \\
\hline & 2012 & 0.019 & 0.0412 & 0.0383 & 0.08 & 0.9301 & 0.0475 & 0.035887046 & 0.027545536 & 0.069905574 \\
\hline & 2011 & 0.014 & 0.0312 & 0.0291 & 0.07 & 0.9333 & 0.042 & 0.021001841 & -0.003644478 & 0.066731171 \\
\hline & 2010 & 0.055 & 0.1184 & 0.1098 & 0.08 & 0.9271 & 0.0526 & 0.043344071 & 0.019618847 & 0.072929956 \\
\hline
\end{tabular}




\begin{tabular}{|c|c|c|c|c|c|c|c|c|c|c|}
\hline & & EPS & ROE & ROA & TL/TE & EQ/TA & DYIELD & GDPG & INFL & TL/TA \\
\hline & 2009 & 0.048 & 0.1124 & 0.1055 & 0.07 & 0.9381 & 0.0633 & 0.025397725 & 0.027955128 & 0.061896972 \\
\hline \multirow{5}{*}{ BMMI } & 2013 & 0.08 & 0.1879 & 0.1329 & 0.41 & 0.7071 & 0.0617 & 0.053375385 & 0.031892481 & 0.292859498 \\
\hline & 2012 & 0.069 & 0.1724 & 0.1311 & 0.31 & 0.7588 & 0.082 & 0.035887046 & 0.027545536 & 0.235157071 \\
\hline & 2011 & 0.053 & 0.1395 & 0.106 & 0.32 & 0.7507 & 0.0877 & 0.021001841 & -0.003644478 & 0.243458511 \\
\hline & 2010 & 0.073 & 0.1905 & 0.1497 & 0.28 & 0.7795 & 0.0775 & 0.043344071 & 0.019618847 & 0.215685954 \\
\hline & 2009 & 0.079 & 0.2021 & 0.1562 & 0.29 & 0.7727 & 0.0758 & 0.025397725 & 0.027955128 & 0.223455273 \\
\hline \multirow{5}{*}{ BFM } & 2013 & 0.009 & 0.0118 & 0.0094 & 0.26 & 0.7926 & 0.0284 & 0.053375385 & 0.031892481 & 0.207393779 \\
\hline & 2012 & 0.028 & 0.045 & 0.0403 & 0.12 & 0.8965 & 0.0588 & 0.035887046 & 0.027545536 & 0.103527607 \\
\hline & 2011 & 0.033 & 0.0492 & 0.0394 & 0.25 & 0.8015 & 0.05 & 0.021001841 & -0.003644478 & 0.198527643 \\
\hline & 2010 & 0.028 & 0.0434 & 0.0339 & 0.28 & 0.7821 & 0.05 & 0.043344071 & 0.019618847 & 0.217914632 \\
\hline & 2009 & 0.044 & 0.0698 & 0.0589 & 0.19 & 0.8434 & 0.0431 & 0.025397725 & 0.027955128 & 0.156554829 \\
\hline \multirow{5}{*}{ BANDER } & 2013 & -0.001 & -0.0084 & -0.0069 & 0.22 & 0.8222 & 0 & 0.053375385 & 0.031892481 & 0.177819825 \\
\hline & 2012 & -0.001 & -0.0103 & -0.0081 & 0.26 & 0.7927 & 0 & 0.035887046 & 0.027545536 & 0.207282913 \\
\hline & 2011 & -0.07 & -0.0068 & -0.0051 & 0.34 & 0.749 & 0 & 0.021001841 & -0.003644478 & 0.251000627 \\
\hline & 2010 & -0.015 & -0.0012 & -0.0012 & 0.07 & 0.9314 & 0 & 0.043344071 & 0.019618847 & 0.068627451 \\
\hline & 2009 & 0.035 & 0.0033 & 0.0031 & 0.05 & 0.9545 & 0 & 0.025397725 & 0.027955128 & 0.045468024 \\
\hline \multirow{5}{*}{ BASREC } & 2013 & 0.056 & 0.0472 & 0.0424 & 0.11 & 0.8983 & 0.019 & 0.053375385 & 0.031892481 & 0.101702754 \\
\hline & 2012 & 0.079 & 0.0667 & 0.0595 & 0.12 & 0.8915 & 0.025 & 0.035887046 & 0.027545536 & 0.108468363 \\
\hline & 2011 & 0.163 & 0.1266 & 0.1155 & 0.1 & 0.9125 & 0.0294 & 0.021001841 & -0.003644478 & 0.087527062 \\
\hline & 2010 & 0.139 & 0.1141 & 0.1031 & 0.11 & 0.904 & 0.0307 & 0.043344071 & 0.019618847 & 0.095940101 \\
\hline & 2009 & 0.146 & 0.1146 & 0.1037 & 0.11 & 0.9048 & 0.0281 & 0.025397725 & 0.027955128 & 0.095209064 \\
\hline \multirow{5}{*}{ BATELCO } & 2013 & 0.028 & 0.0808 & 0.0418 & 0.83 & 0.5176 & 0.0667 & 0.053375385 & 0.031892481 & 0.430852534 \\
\hline & 2012 & 0.038 & 0.1173 & 0.0875 & 0.33 & 0.7461 & 0.0619 & 0.035887046 & 0.027545536 & 0.245423344 \\
\hline & 2011 & 0.056 & 0.1582 & 0.1214 & 0.28 & 0.7672 & 0.102 & 0.021001841 & -0.003644478 & 0.213278488 \\
\hline & 2010 & 0.06 & 0.1718 & 0.1318 & 0.28 & 0.7669 & 0.0882 & 0.043344071 & 0.019618847 & 0.215128684 \\
\hline & 2009 & 0.073 & 0.2129 & 0.1561 & 0.34 & 0.7329 & 0.0847 & 0.025397725 & 0.027955128 & 0.251118744 \\
\hline \multirow{4}{*}{ ALBH } & 2013 & 0.057 & 0.0919 & 0.0677 & 0.36 & 0.7371 & 0.0684 & 0.053375385 & 0.031892481 & 0.262948981 \\
\hline & 2012 & 0.068 & 0.1164 & 0.0797 & 0.46 & 0.6845 & 0.0648 & 0.035887046 & 0.027545536 & 0.315464506 \\
\hline & 2011 & 0.15 & 0.262 & 0.1624 & 0.61 & 0.6199 & 0.1015 & 0.021001841 & -0.003644478 & 0.380135501 \\
\hline & 2010 & 0.098 & 0.1978 & 0.1042 & 0.9 & 0.5267 & 0.0586 & 0.043344071 & 0.019618847 & 0.473326031 \\
\hline
\end{tabular}

\section{References}

[1] Abbasali Pouraghajan, Esfandiar Malekian, Milad Emamgholipour, Vida Lotfollahpour \& Mohammad Mohammadpour Bagheri (2012) "The Relationship between Capital Structure and Firm Performance Evaluation Measures: Evidence from the Tehran Stock Exchange" International Journal of Business and Commerce, Vol. 1, No. 9, 166-181. Retrieved from www.ijbcnet.com

[2] Abdul, G .K. (2012). The Relationship of Capital Structure Decisions with Firm Performance: A Study of the Engineering Sector of Pakistan, International Journal of Accounting and Financial Reporting, 2(1), 2162-3082.

[3] Hutchinson RW (1995), "The capital structure and investment decisions of the small owner-managed firm: Some explanatory issues", Small Business Economics, vol. 7, pp.231.

[4] Ibrahim El-Sayed E. (2009). "The Impact of Capita-structure choice on firm Performance: Empirical evidence from Egypt. "The Journal of Risk Finance, vol. 10, No.5, 477-487

[5] IMF (2015), International Financial statistics, available at www.imf.org

[6] Javed, B. \& Akhtar,S. (2012) Interrelationships between Capital Structure and Financial Performance, Firm Size and Growth: Comparison of industrial sector in KSE: European Journal of Business and Management, 4(15), 148-157.

[7] Kaumbuthu,A.J. (2011) "The relationship between capital structure and financial performance: a study of firms listed under industrial and allied sector at the NSE",(MBA Dissertation, University of Nairobi), retrieved from http://erepository.uonbi.ac.ke.

[8] Mahfuzah Salim and Raj Yadav (2012) "Capital Structure and Firm Performance: Evidence from Malaysian Listed Companies", International Congress on Interdisciplinary Business and Social Science- Social and Behavioral Sciences 65 pp. $156-166$.

[9] Maina, L. \& Kondongo, O. (2013) Capital Structure and Financial Performance in Kenya: Evidence from Firms Listed at the Nairobi Securities Exchange. Paper Presented at the Jomo Kenyatta University of Science and Technology Research Conference, Kenya.

[10] Marc L. Nerlove (1968), "Factors Affecting Differences among Rates of Return on Investments in Individual Common Stocks," Review of Economics and Statistics, 50: 312-31.

[11] Modigliani, F. and M.H Miller (1958) "The Cost of Capital, Corporate Finance and the theory of investment", American Economic Review, vol. 48, 261-97

[12] Mubeen Mujahid and Kalsoom Akhtar (2014) "Impact of Capital Structure on Firms Financial Performance and Shareholders Wealth: Textile Sector of Pakistan", International Journal of Learning \& Development Vol. 4, no. 2. Retrieved from: http://dx.doi.org/10.5296/ijld.v4i2.5511

[13] Mwangi, Lucy Wamugo, Makau, Muathe Stephen, and Kosimbei, George (2014) "Relationship between Capital Structure and Performance of Non-Financial Companies Listed In the Nairobi Securities Exchange, Kenya". Global Journal of Contemporary Research in Accounting, Auditing and Business Ethics, Vol: 1 Issue 2. 
[14] Nimalathasan and Valeriu Brabete (2010), Capital structure and its impact on profitability: A study of listed manufacturing companies listed in Srilanka.

[15] Ogebe, Ojah Patrick, Joseph Orinya Ogebe, and Kemi Alewi (2013) "The Impact of Capital Structure on Firms' Performance in Nigeria", online at http://mpra.ub.unimuenchen.de/45986/ MPRA Paper No. 45986, posted 8. April 2013 20:10 UTC.

[16] Prahalathan B, Dr. RPC Ranjani (2011). "The Impact of capital Structure -Choice on Firm Performance: Empirical Investigation of Listed companies in Colombo Stock Exchange, Sri Lanka". International Journal of Research Commerce Management, Volume 2

[17] Rajan, R. and L. Zingales, (1995), "What Do We Know about Capital Structure: Some Evidence from International Data," Journal of Finance 50, 1421-1460.
[18] Tharmila K. and Arulvel K. K. (2013) "The impact of the capital structure and financial performance: A study of the listed companies traded in Colombo stock exchange Merit Research Journal of Accounting, Auditing, Economics and Finance Vol. 1(5) pp. 106-117. Retrieved online at http://www.meritresearchjournals.org/aaef/index.htm

[19] Wooldridge, (2004), Introduction to Modern Bayesian Econometrics by Tony Lancaster, Wiley-Blackwell (2004, 416pp)

[20] Zuraidah Ahmad, Norhasniza Mohd Hasan Abdullah and Shashazrina Roslan (2012) "Capital Structure Effect on Firms Performance: Focusing on Consumers and Industrials Sectors on Malaysian Firms" International Review of Business Research Papers Vol. 8. No.5, 137 - 155. 